\title{
High-affinity binding sites for the Deformed protein are required for the function of an autoregulatory enhancer of the Deformed gene
}

\author{
Michael Regulski, ${ }^{1,3}$ Scott Dessain, ${ }^{1}$ Nadine McGinnis, ${ }^{2}$ and William McGinnis ${ }^{1,2}$ \\ Departments of Biology ${ }^{1}$ and Molecular Biophysics and Biochemistry ${ }^{2}$ Yale University, New Haven, Connecticut 06511 \\ USA
}

The homeotic selector gene Deformed $(D f d)$ is required to specify the identity of head segments during Drosophila development. Previous experiments have shown that for the $D f d$ segmental identity function to operate in epidermal cells, the $D f d$ gene must be persistently expressed. One mechanism that provides persistent embryonic expression of $D f d$ is an autoregulatory circuit. Here, we show that the control of this autoregulatory circuit is likely to be directly mediated by the binding of Dfd protein to an upstream enhancer in $D f d$ locus DNA. In a $25-\mathrm{kb}$ region around the $D f d$ transcription unit, restriction fragments with the highest binding affinity for Dfd protein map within the limits of the upstream autoregulatory element at approximately $-5 \mathrm{~kb}$. A minimal autoregulatory element, within a 920-bp segment of upstream DNA, has four moderate- to high-affinity binding sites for Dfd protein, with the two highest affinity sites sharing an ATCATTA consensus sequence. Site-specific mutagenesis of these four sites results in an element that has low affinity for Dfd protein when assayed in vitro and is nonfunctional when assayed in embryos.

[Key Words: Deformed; autoregulatory circuit; homeo domain, homeotic protein]

Received October 26, 1990; revised version accepted December 13, 1990.

The pattern of the Drosophila body plan along the anteroposterior axis is defined through a complex hierarchy of interactions among several classes of pattern formation genes (for review, see Akam 1987; Ingham 1988). At the bottom of this hierarchy are the homeotic selector genes that specify unique identities to specific body compartments along the anteroposterior axis /GarciaBellido 1977; Lewis 1978; Wakimoto and Kaufman 1981). Genes of the homeotic selector class exert regulatory effects on each other and themselves to maintain their respective expression patterns in the embryo (Struhl 1982; Hafen et al. 1984; Carroll et al. 1986; Bienz and Tremmel 1988; Kuziora and McGinnis 1988). They are also believed to regulate the transcription of downstream "realisator" genes, which would be responsible for the formation of particular structures in individual segments (Garcia-Bellido 1977; Gonzalez-Reyes and Morata 1990; Immergluck et al. 1990).

The homeotic selector genes of the Antennapedia and Bithorax complexes share similar 180-bp sequences called homeo boxes (McGinnis et al. 1984a,b; Scott and Weiner 1984; Regulski et al. 1985). Homeo box sequences are found in many other genes involved in the

${ }^{3}$ Present address: Department of Biology, Brandeis University, Waltham, Massachusetts 02254 USA. regulation of Drosophila development (Poole et al. 1985; Frigerio et al. 1986; for review, see Scott et al. 1989) and are highly conserved in many higher and some lower animals (Carrasco et al. 1984b; McGinnis et al. 1984; McGinnis 1985; Way and Chalfie 1988; Scott et al. 1989). Homeo box sequences encode a family of sequence-specific DNA-binding protein domains, collectively referred to as homeo domains (Desplan et al. 1985, 1988; Fainsod et al. 1987; Hall and Johnson 1987; Hoey and Levine 1988; Muller et al. 1988). Homeo domain proteins can mediate transcriptional activation or repression when tested in cotransfection assays in tissue culture cells or in transcription assays in vitro (Jaynes and O'Farrell 1988; Thali et al. 1988; Biggin and Tjian 1989; Han et al. 1989; Krasnow et al. 1989; Winslow et al. 1989|. However, most tissue culture and in vitro experiments have been done with DNA sequences whose relevance to embryonic regulatory function(s) is questionable or nonexistent.

At present, the best described embryonic DNA targets for Drosophila homeo domain proteins are those that map just upstream of the hunchback and fushi tarazu gene transcription initiation sites. A 300-bp element of hunchback upstream DNA directs expression of hunchback transcripts in the anterior half of the early blastoderm embryo in a bicoid $(b c d)$-dependent manner and 
has multiple binding sites for the homeo domain-containing bcd protein (Tautz 1988; Driever and NüssleinVolhard 1989a; Struhl et al. 1989|. Deletions of portions of the element that include bcd protein-binding sites inactivate its function. In addition, multimerized fragments of the element that include little additional sequence flanking the bcd protein-binding sites are capable of providing hunchback-like expression patterns that are sensitive to the levels of bcd protein (Driever et al. 1989b; Struhl et al. 1989). An 300-bp element of fushi tarazu upstream DNA provides expression in the posterior half of the early embryo (Dearolf et al. 1989). This fushi tarazu element has two pairs of binding sites for the homeo domain-containing caudal protein. The mutation of either pair of binding sites abolishes the function of the element (Dearolf et al. 1989).

Though many cross- and autoregulatory relationships exist among the homeotic selectors, the target sequences that mediate these effects are largely undefined. The two selector regulatory elements whose limits are best defined are autoregulatory elements at Ultrabithorax $(U b x)$ and Deformed $(D f d)$. The $U b x$ autoregulatory element maps between -3.1 and $-1.7 \mathrm{~kb}$ from the $U b x$ transcription start and confers late expression in parasegment 7 of the visceral mesoderm (Bienz and Tremml 1988; Muller et al. 1989|. The Dfd autoregulatory element maps between -6.6 and $-3.9 \mathrm{~kb}$ from the $D f d$ transcription start and normally provides expression in the maxillary and mandibular epidermis (Bergson and McGinnis 1990).

$D f d$ is a homeotic selector gene that specifies the identity of mandibular and maxillary lobes in Drosophila embryos (Chadwick and McGinnis 1987; Merrill et al. 1987; Regulski et al. 1987). We have shown previously that persistent embryonic expression from $D f d$ is required for its segment identity function and that persistent expression is maintained by autoregulation through a distant upstream enhancer (Kuziora and McGinnis 1988; Bergson and McGinnis 1990). Here we provide evidence consistent with a direct interaction between the $D f d$ protein and the Dfd autoregulatory element. Using stringent DNA-binding conditions to test fragments in a $25-\mathrm{kb}$ region, including the $D f d$ transcription unit and flanking regions, we find that the region with the highest binding affinity for $D f d$ protein is located within the $D f d$ autoregulatory element. Site-specific mutagenesis of some of the high-affinity Dfd protein-binding sites abolishes the activity of a minimal autoregulatory element.

\section{Results}

\section{Dfd protein}

Current results are consistent with either a direct or an indirect effect of Dfd protein on $D f d$ autoregulation. If Dfd protein directly mediates its positive regulatory effect on the Dfd transcription unit, we expected to find restriction fragments in $D f d$ genomic sequences with significant binding affinity for Dfd protein. To test for such binding fragments, we used Dfd protein that had been overproduced in either bacterial cells or Drosophila embryos. $D f d$ encodes a homeo domain protein of 586 amino acids (Regulski et al. 1987). To produce full-length Dfd protein in Escherichia coli, we used the T7 expression system (Studier and Moffatt 1986) and the expression plasmid pAR3040Dfd (Jack et al. 1988). After induction, Dfd protein constitutes $\sim 5 \%$ of total protein in a soluble extract from these cells. For some of the following experiments, bacterially produced Dfd protein was purified using sequence-specific DNA affinity chromatography (Fig. 1, lane 4). The identity of Dfd protein in the bacterial extract and in affinity chromatography fractions was confirmed by Western blot analysis (Fig. 1A, lanes 2'-4') using anti-Dfd antiserum (Jack et al. 1988). We also prepared a Drosophila nuclear extract from

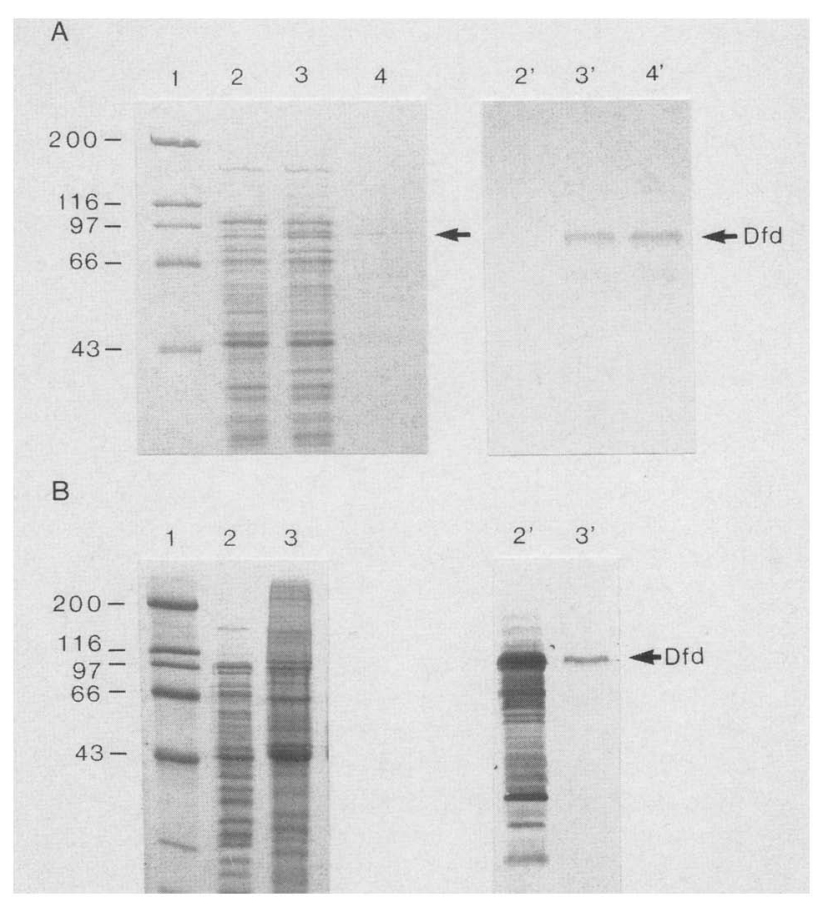

Figure 1. Dfd protein and extracts. $(A)$ Purification of fulllength Dfd protein from $E$, coli extracts. (Lane 1) Molecular weight markers, with their sizes in kilodaltons indicated on the left; (lane 2) $8 \mu \mathrm{g}$ of soluble protein extract prepared after induction of an $E$. coli strain containing the control pAR3040 plasmid; (lane 3) $8 \mu \mathrm{g}$ of soluble protein extract prepared after induction of an E. coli strain containing pAR3040Dfd plasmid; (lane 4) $350 \mathrm{ng}$ of purified Dfd protein from a $0.6 \mathrm{M} \mathrm{NaCl}$ fraction of a DNA-affinity column. (Lanes $2^{\prime}-4^{\prime}$ ) The equivalent of lanes 2-4 was transferred to nitrocellulose and the Dfd protein was detected with anti-Dfd antiserum (Jack et al. 1988). (B) Identification of the Dfd protein in the nuclear extract from Drosophila embryos. The extract was prepared from transgenic embryos carrying $h s p 70-D f d$ construct after heat shock induction of Dfd protein expression. (Lane 1) Molecular weight markers; (lane 2) $13 \mu \mathrm{g}$ of soluble bacterial protein extract containing the Dfd protein; (lane 3) $20 \mu \mathrm{g}$ of embryonic nuclear protein extract. (Lanes $2^{\prime}$ and $3^{\prime}$ ) The equivalent of lanes 2 and 3 , respectively, was transferred to nitrocellulose and reacted with anti-Dfd antiserum to detect Dfd protein. The arrow indicates the position of the Dfd protein. 
hsp70-Dfd embryos (Kuziora and McGinnis 1988) to compare the binding specificity of the $E$. coli-produced Dfd protein to that produced in embryos (Fig. 1B).

\section{DNA fragments in the Dfd locus that bind Dfd protein}

We used a modified version of an immunoprecipitation assay (McKay 1981) to identify DNA fragments with high affinity for the Dfd protein within the $D f d$ genomic region. As the input DNA we used digests of two $\lambda$ phage DNAs that contain $25 \mathrm{~kb}$ of Antennapedia complex DNA: $\lambda 100$, which contains $8 \mathrm{~kb}$ of $D f d$ upstream sequence and the $5^{\prime}$ half of the $11-\mathrm{kb} D f d$ transcription unit; and $\lambda 99$, which contains the 3 ' half of the transcription unit and $6 \mathrm{~kb}$ of downstream sequences (Regulski et al. 1987). Restriction fragments of these two phage DNAs were incubated with bacterial or embryonic nuclear extracts containing Dfd protein, and bound fragments were immunoprecipitated with anti-Dfd antiserum. As a control for the specificity of the immunoprecipitation we used bacterial extract without Dfd protein. Figure $2 \mathrm{~A}$ shows the results of an experiment in which the input DNA was digested with $A c c$ I and HindII endonucleases and the immunoprecipitated fragments were separated on an agarose gel. Within $\lambda 100$ DNA, an AccI-HindIII fragment of 540 bp had the highest affinity for Dfd protein produced either in bacteria (lane 2) or embryos (lane 3). No fragments are immuno- precipitated by control bacterial extracts that lack Dfd protein (lane 4). Within $\lambda 99$ DNA, the highest affinity fragment is a $2.3-\mathrm{kb}$ HindIII fragment that was bound strongly by Dfd protein from embryonic extracts but was bound weakly by Dfd protein produced in E. coli.

Because small DNA fragments might go undetected on agarose gels, we also separated immunoprecipitated fragments on polyacrylamide gels (Fig. 2B). In the experiment shown, $\lambda 100$ and $\lambda 99$ DNAs were digested with EcoRI and HindIII. Again, both protein preparations showed similar binding specificity on $\lambda 100$ fragments, with highest affinity for a 900-bp HindIII fragment. This fragment includes the 540-bp Accl-HindIII fragment immunoprecipitated in Figure $2 \mathrm{~A}$. In the lanes containing $\lambda 99$ digests, the same $2.3-\mathrm{kb}$ HindIII fragment is preferentially bound by embryonic extract (lane 9). When used in relatively large amounts, the bacterially produced Dfd protein exhibits the same binding specificity on $\lambda 99 \mathrm{frag}$ ments as does embryonic extract (Fig. 2B, lane 7). However, at low concentrations, the bacterially produced Dfd protein has an apparent higher affinity for the 900-bp fragment than for the 2.3-kb HindIII fragment.

The location of one of the high-affinity binding regions correlates nicely with sequences that we have previously shown can provide autoregulated expression of $D f d$ (Bergson and McGinnis 1990). A $D f d$ autoregulatory enhancer maps between -3.9 and $-6.6 \mathrm{~kb}$ from the transcription start (Fig. 3). In wild-type embryos, this en-

Figure 2. DNA fragments binding Dfd protein within the Dfd genomic region. DNA from phages $\lambda 100$ and $\lambda 99$ was digested with restriction enzymes, end-labeled with ${ }^{32} \mathrm{P}$, incubated with protein extract, and immunoprecipitated with the anti-Dfd antiserum. Products were resolved on agarose $(A)$ or polyacrylamide $(B, C)$ gels. $(A)$ Lanes $1-4$ show the results of an immunoprecipitation experiment with $\lambda 100$ DNA digested with $A C C I$ and HindIII endonucleases; (lanes 58 ) the results with $\lambda 99$ DNA, also digested with AccI and HindIII; (lanes 1-5) the input DNA fragments; (lanes 2-6) DNA fragments bound and precipitated in presence of $0.25 \mu \mathrm{g}$ of a soluble $E$. coli protein extract containing the Dfd protein; (lanes $3-7$ ) the fragments bound by 76 $\mu \mathrm{g}$ of Drosophila embryo nuclear extract. Lanes 4 and 8 are controls, showing that no fragments are bound by $0.25 \mu \mathrm{g}$ of soluble $E$. coli protein

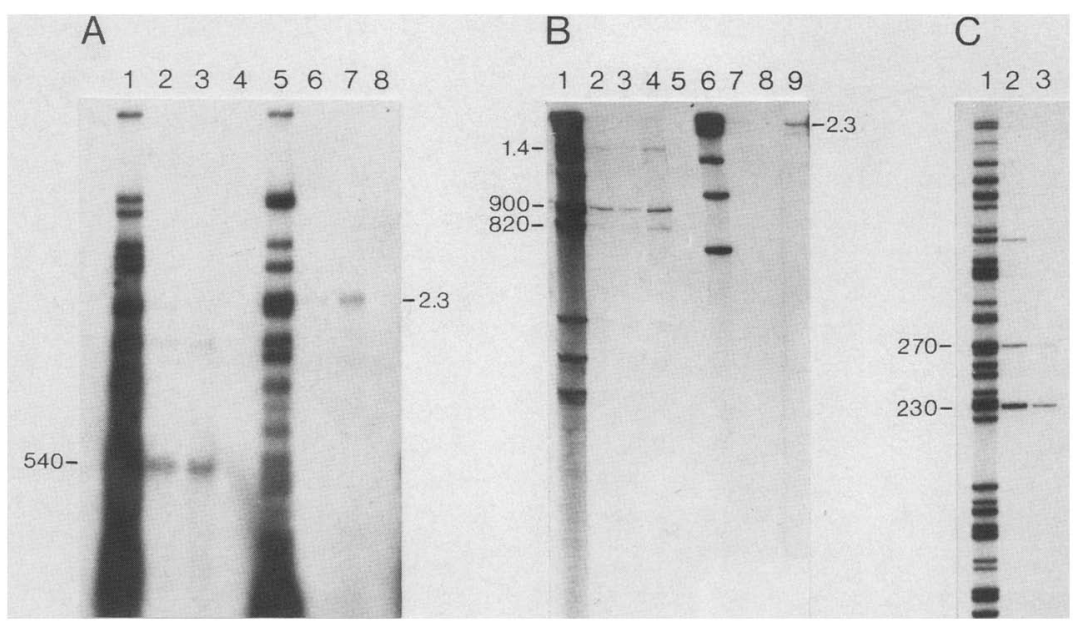
extract without Dfd protein. The sizes of fragments with high affinity for Dfd protein are indicated: 900 -bp HindIII and 540 -bp AccI-HindIII fragments within $\lambda 100$, and a $2.3-\mathrm{kb}$ HindIII fragment within $\lambda 99$. $(B)$ Lanes $1-5$ show the results of an immunoprecipitation experiment with $\lambda 100$ DNA digested with EcoRI and HindIII endonucleases; (lanes $6-9$ ) the results of an identical experiment with 199 DNA presented in the same order except for the minus-Dfd lane, which was omitted. (Lanes 1 and 6) The input DNA fragments. (Lanes 2 and 7) The DNA fragments bound and precipitated in the presence of $0.5 \mu \mathrm{g}$ of a soluble $E$. coli protein extract containing the Dfd protein; (lanes 3 and 8 ) the results when $0.25 \mu \mathrm{g}$ of the same extract is used. (Lanes 4 and 9 ) The fragments bound by $76 \mu \mathrm{g}$ of Drosophila embryonic nuclear extract. Lane 5 is a control, showing that no fragments are bound by $0.5 \mu \mathrm{g}$ of soluble $E$. coli protein extract without the Dfd protein. The sizes of fragments with moderate to high affinity for Dfd protein are indicated: the 1.4-kb HindIII-EcoRI, the 900-bp HindIII, and the 820-bp EcoRI fragments of $\lambda 100$, and the $2.3-\mathrm{kb}$ HindIII fragment of $\lambda 99$. The location of these binding fragments relative to the Dfd transcription unit is shown in Fig. 3. (C) HZ2.7 DNA (Bergson and McGinnis 1990), which contains the $2.7-\mathrm{kb} \mathrm{XbaI}$ fragment from -3.9 to -6.6 (Fig. 3) was tested in an immunoprecipitation experiment after digestion with AluI. (Lane 1) The input DNA fragments; (lanes 2 and 3) the fragments precipitated with 0.5 and $0.15 \mu g$, respectively, of a soluble E. coli extract containing Dfd protein. The 230- and 270-bp AluI fragments with highest affinity for the Dfd protein are marked by arrowheads. The third fragment visible in lane 3 derives from the vector PLHZ50 (Hiromi and Gehring 1987). 


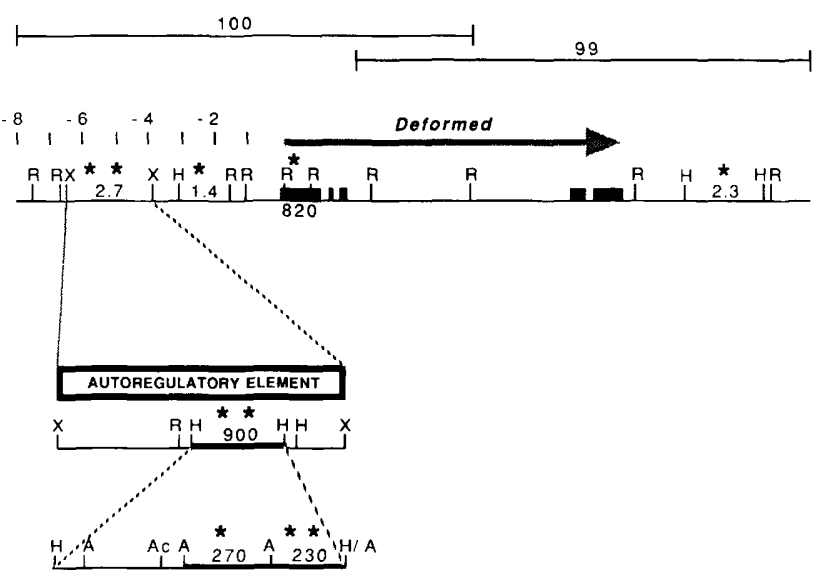

Figure 3. Map of fragments that bind Dfd protein. The top half shows a simplified restriction map of the Antennapedia complex region included in clones $\lambda 100$ and $\lambda 99$. Solid blocks on the map represent the exons of the 1l-kb $D f d$ transcription unit, and the arrow shows the direction of transcription. The scale over the upstream region measures the distance from the $D f d$ transcription start site in kilobases. (Bottom) A more detailed map of the $D f d$ autoregulatory enhancer (Bergson and McGinnis 1990|. Asterisks mark fragments in the region with relatively high $(* *)$ and low (*) affinity for $E$. coli-produced Dfd protein in immunoprecipitation assays. (R) EcoRI; (X) XbaI; (H) HindIII; (Ac) AccI; (A) AluI.

hancer provides late, spatially localized expression in the epidermal cells of the maxillary and mandibular segment and in $D f d$-expressing regions of the eye-antennal imaginal disc. In $D f d$ mutant embryos, the enhancer is inactive, and in hsp70-Dfd embryos it is ectopically activated (Bergson and McGinnis 1990). The smallest known subelement of the enhancer that provides maxillary-specific expression is contained within the same 900-bp HindIII fragment that has high binding affinity for Dfd protein. The 900-bp HindIII fragment containing this $D f d$ minimal element maps between -4.5 and $-5.4 \mathrm{~kb}$ from the transcription start site (Fig. 3).

The 2.3-kb HindIII fragment (Fig. 3), with high affinity for Dfd protein-containing embryonic extracts, is unlikely to have an important role in the regulation of $D f d$ expression based on the variant $D f d$ locus in the $D f d^{R \times 17}$ chromosome. The $D f d^{R X 17}$ locus contains a $35-\mathrm{kb}$ DNA insert that maps between the $D f d$ polyadenylation site and the 2.3-kb HindIII fragment, yet exhibits a normal $D f d$ expression pattern during embryonic and larval stages (Chadwick et al. 1990).

To further delimit regions within the 900-bp HindIII fragment for their relative affinity for Dfd protein, we analyzed binding of an AluI digest of a $2.7-\mathrm{kb}$ XbaI subclone of $\lambda 100$ (Fig. 3), which contains the 900-bp fragment and surrounding sequences. As shown in Figure 2C, bacterially produced Dfd protein preferentially binds two subregions of the 900-bp HindIII fragment. The highest affinity binding region is within a 230-bp AluI fragment, and a lower affinity binding region maps within an adjacent 270-bp AluI fragment. The same pattern of binding preferences was obtained for the embryonically produced Dfd protein (data not shown).

\section{Dfd-binding sites within the 270/230-bp AluI fragments}

The overlap between the position of the $D f d$ autoregulatory element and fragments with high binding affinity for Dfd protein is consistent with the hypothesis that Dfd protein might be directly involved in autoregulation. To begin to test this, we first needed to define the specific DNA sequences binding the Dfd protein. As the 270- and 230-bp AluI fragments had the highest affinities for Dfd protein in immunoprecipitation assays, we used purified Dfd protein and DNase I protection assays $/ \mathrm{Ga}$ las and Schmitz 1978) to identify Dfd protein-binding sites in this region. Footprint data for the highest affinity sites is shown in Figure 4. There is one high-affinity binding site, $\mathrm{A}$, in the 270-bp AluI fragment (Fig. 4A) and three moderate- to high-affinity sites, $B, C$, and D, within the 230-bp AluI fragment (Fig. 4B,C). The map in Figure

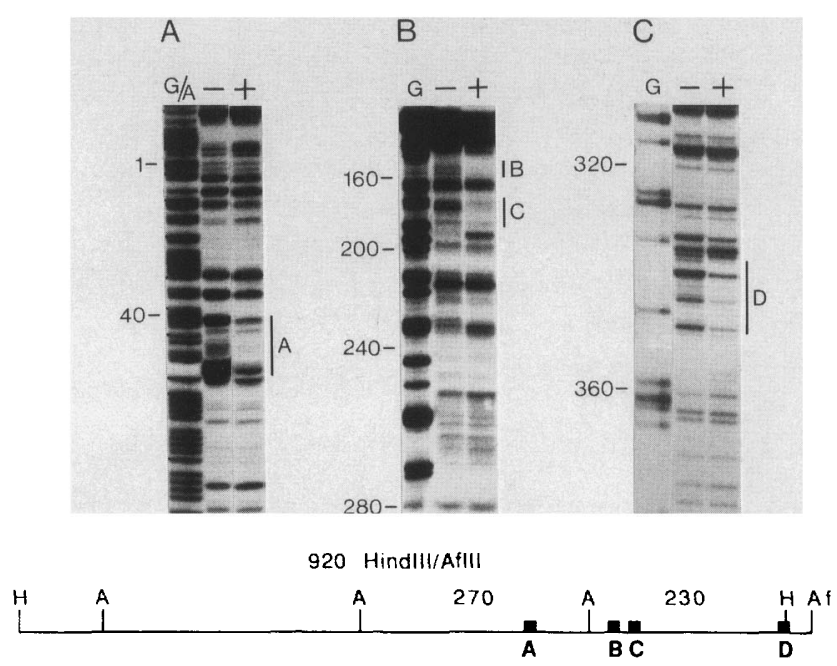

Figure 4. Dfd-binding sites within the 230- and 270-bp AluI fragments. One femtomole of labeled DNA fragment was bound with $180 \mathrm{ng}$ of purified Dfd protein (Fig 1), digested with DNase I, and resolved on denaturing polyacrylamide gel. Regions protected from DNase I digestion are marked by the labeled line at the right of $A, B$, and $C$. (G or G/A) Maxam/Gilbert sequencing ladders of the respective footprinted fragments; $1+\mid$ DNase I digestion products of binding reaction with Dfd protein; $(-)$ control digestions done in the absence of Dfd protein. The nucleotide numbering scheme on the left of each panel corresponds to that shown in Fig. 5A. The specific restriction fragments used in each protection experiment are listed below; all were labeled at the $3^{\prime}$ ends of their upper strands. (A) A BamHIEcoRI fragment from pBST270, which contains the 270-bp AluI fragment. (B) An EcoRI-BamHI fragment from pBS230, which contains the 230-bp AluI fragment. (C) An EcoRI-Sall fragment from pBST475, which contain 230-bp AluI and flanking sequences. (Bottom) A map of the 920-bp HindIII-AfIII fragment showing the positions of four moderate- to high-affinity Dfd protein-binding sites. AluI-(A), AfIII-(Af), and HindIII-(H) restriction sites are shown. 
4 shows the location of these sites within a 920-bp HindIII-AfIII fragment.

The DNA sequence of the region containing these four binding sites is shown in Figure 5A. Sites A and D share a perfect sequence match of $7 \mathrm{bp}$ : ATCATTA. The A and $D$ sites appear to have higher affinity for the Dfd protein in the footprinting experiments than sites $B$ and $C$, as they are protected at slightly lower concentrations of protein (data not shown). Figure $5 \mathrm{~B}$ shows the ATCATTA high-affinity consensus sequence aligned with the consensus binding sequences of some other homeodomain-containing proteins. At least within the autoregulatory element, Dfd protein appears to prefer sites with ATC just $5^{\prime}$ to an ATTA core (or GAT just $3^{\prime}$ to a TAAT core), while other homeo domain proteins have different preferred bases adjacent to the core in their consensus sequences.

Dfd protein-binding sites are required for function of $a$ minimal autoregulatory element

To test whether sites A-D in the minimal autoregulatory element are required for its function, we used in vitro site-specific mutagenesis (Kunkel et al. 1987) to alter the four Dfd-binding sites. In sites $A$ and $D$ the ATTA core was replaced with CCCC, and in sites B and $C$ the sequence AATTA was changed to CCCCC. The quadruply mutated regulatory region was then cloned as a 920-bp HindIII-AfIII fragment (from the left end of the 900-bp HindIII fragment to just downstream of the now mutated HindIII site, since site D overlaps the HindIII site at the left end of the 900-bp fragment), upstream of the $h s p 70$ basal promoter-lacZ reporter gene in the $\mathrm{P}$ element transformation vector HZ50 (Hiromi and Ge- hring 1987). We then generated germ-line transformants carrying the quadruply mutant autoregulatory element (Q920-HZ strains) and control strains carrying the wildtype 920-bp fragment in the HZ50 vector $1920-\mathrm{HZ}$ strains).

The mutation of sites A-D results in 920-bp fragments with little specific affinity for Dfd protein in vitro. As shown in Figure 6A, the wild-type fragment is strongly bound and immunoprecipitated by moderate concentrations of Dfd protein. Similar amounts of Dfd protein do not give detectable binding of the Q920 fragment. At higher concentrations of Dfd protein, some binding of the Q920 fragment can be detected, but the affinity appears to be not much greater than other nonspecifically bound fragments from the HZ50 host plasmid (Fig. 6).

Expression patterns in the $920-\mathrm{HZ}$ strains are similar to that in the previously described HZ0.9 transformants (Bergson and McGinnis 1990). $\beta$-Galactosidase is expressed in a subset of the normal Dfd expression domain in the maxillary segment, from $\sim 12 \mathrm{hr}$ after egg laying (AEL) to the end of embryogenesis $8 \mathrm{hr}$ later (Fig. 6B). We tested three Q920-HZ strains carrying the quadruply mutated regulatory constructs. None of these strains express $\beta$-galactosidase in the maxillary segment at any stage of embryonic development (Fig. 6C).

Surprisingly, the function of the entire epidermal autoregulatory element in the 2.7-kb Xbal fragment (Fig. 3; Bergson and McGinnis 1990) was not noticeably affected by the mutation of sites A-D. Strains carrying Q2.7-HZ expression constructs exhibited a pattern of maxillaryspecific expression identical to $2.7-\mathrm{HZ}$ (Bergson and McGinnis 1990). However, the $2.7-\mathrm{kb} \mathrm{XbaI}$ fragment with mutations in sites $A-D$ still possessed considerable specific binding affinity for Dfd protein in vitro, some-
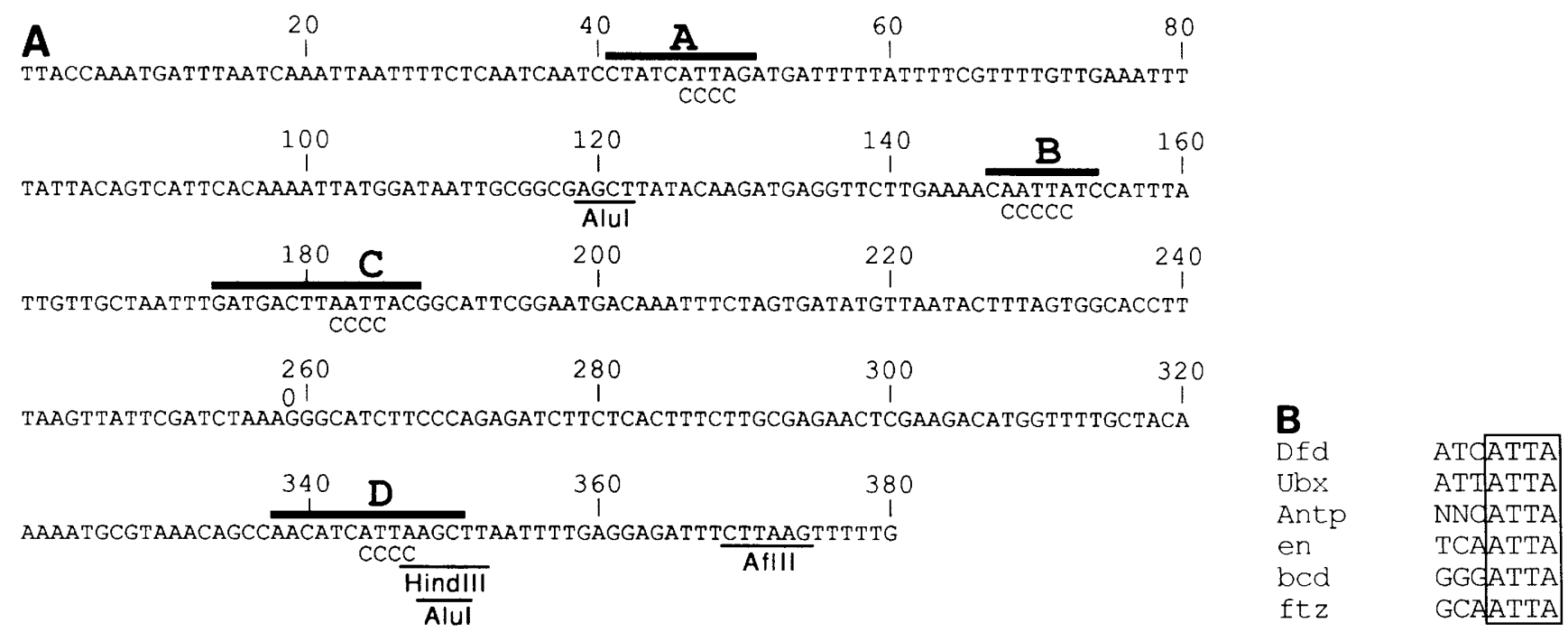

Figure 5. Summary of the DNase I protection analysis. $(A \mid$ The DNA sequence of the region that includes the four moderate- to high-affinity Dfd protein-binding sites. The extent of protected regions is indicated by lines. The Cs below the binding sites indicate the residues that were changed through site-directed mutagenesis to abolish Dfd protein binding at these sites. $(B)$ A comparison of consensus binding sites for other Drosophila homeo domain proteins [Ubx consensus sequence from Beachy et al. (1988); Antp from Muller et al. (1989); en from Hoey and Levine (1988) and Desplan et al. (1988); bcd from Driever and Nüsslein-Volhard (1989); ftz from Pick et al. (1990)|. The shaded block aligns the ATTA core consensus. 


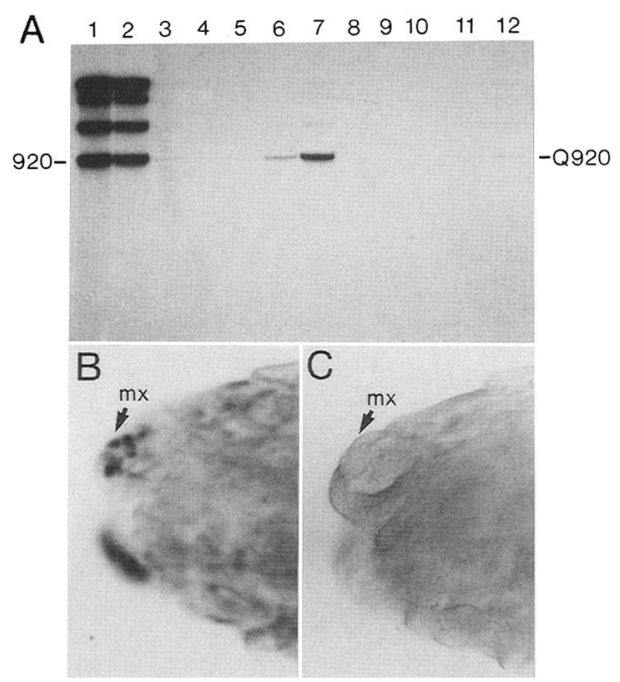

Figure 6. Binding and function of a mutated autoregulatory enhancer element. $(A)$ (Lanes 3-7) The results of immunoprecipitation experiments with $\mathrm{p} 920-\mathrm{HZ}$ plasmid DNA. This plasmid contains the wild-type 920-bp HindIII-AflII fragment upstream of the $h s p 70$ basal promoter-lac $Z$ reporter gene in the P-element transformation vector $\mathrm{HZ} 50$ (Hiromi and Gehring 1987). (Lanes 7-12) The results of similar experiments with pQ920-HZ, which is identical to $\mathrm{p} 920-\mathrm{HZ}$ except for the mutations in sites $A-D$ (Fig. 5). Both plasmids were digested with $B a m H I$ and $X b a I$, which yields a 930-bp fragment that includes the 920-bp minimal autoregulatory element. (Lanes 1 and 2) The input DNA fragments from $\mathrm{p} 920-\mathrm{HZ}$ and pQ920-HZ, respectively. (Lanes 3 and 8 ) The DNA fragments bound and precipitated in the presence of no added protein; (lanes 4 and 9) $7 \mathrm{ng}$ of purified Dfd protein; (lanes 5 and 10) 24 ng of Dfd protein; (lanes 6 and 11) $73 \mathrm{ng}$ of Dfd protein; (lanes 7 and 12) $220 \mathrm{ng}$ of Dfd protein. The positions of the $920-\mathrm{bp}$ fragment, which is strongly bound and precipitated (lane 7) and the Q920 fragment, which is bound at background levels (lane 12), are indicated. $(B)$ Ventrallateral view of the anterior end of a $920-\mathrm{HZ}$ embryo. Staining for $\beta$-galactosidase shows expression of the lac $Z$ reporter gene in cells of the maxillary segment $(\mathrm{mx})$ of this 14-hr embryo. $(C)$ Ventral-lateral view of the anterior end of a Q920-HZ embryo. Staining for $\beta$-galactosidase shows that no expression of the lac $Z$ reporter gene is detected in cells of the maxillary segment $(\mathrm{mx})$ of this 14-hr embryo.

what lower than the wild-type $2.7-\mathrm{kb}$ fragment but much higher than the Q920 fragment (Fig. 6; M. Regulski, unpubl.).

\section{Discussion}

Our results indicate that $D f d$ autoregulation is likely to be directly mediated by the binding of Dfd protein to specific sites in the upstream autoregulatory element. The $D f d$ autoregulatory element is largely contained within a $2.7-\mathrm{kb} \mathrm{XbaI}$ fragment mapping from -3.9 to $-6.6 \mathrm{~kb}$ (Bergson and McGinnis 1990). Within this large element, subelements have been defined that can provide subsets of the late pattern of autoregulated $D f d$ expression. The smallest element yet defined to have autonomous regulatory function is a 900-bp HindIII fragment (Bergson and McGinnis 1990). As we show here, this fragment also has the highest binding affinity for Dfd protein in a 25-kb DNA region including Dfd upstream and downstream sequences. When the four highest affinity Dfd protein-binding sites are mutated in a slightly larger 920 -bp $D f d$ minimal element, its maxillary segment-specific enhancer activity is lost. Because previous studies have shown that similar homeo domain proteins will bind to similar DNA sites, these results prove only that the Dfd-binding sites are required, not that Dfd protein actually binds and activates via these sites in the embyro. However, the above results, in combination with binding studies indicating that the 900-bp HindIII fragment preferentially binds Dfd protein over other similar homeo domain proteins (S. Dessain, unpubl.), strongly support the idea that these binding sites are embryonically relevant target sites for the regulatory activity of Dfd protein.

Although the 900-bp fragment has the most compact cluster of moderate- to high-affinity Dfd-binding sites, the remainder of the epidermal autoregulatory element, which is currently defined by a $2.7-\mathrm{kb} \mathrm{Xbal}$ fragment spanning -6.6 to -3.9 , has additional sites that Dfd protein binds in vitro (C. Gross and S. Dessain, unpubl.). Many of these are likely to be relevant to the function of the intact element, since the function of a $2.7-\mathrm{kb}$ element is not strongly disrupted by the quadruple mutations in the A-D sites (Bergson and McGinnis 1990; M. Regulski, unpubl.|. Our working model for the upstream autoregulatory element is that it is composed of largely independent Dfd-dependent modules that provide epidermal expression in different subregions of the maxillary and mandibular segments and are functionally redundant to some extent (Bergson and McGinnis 1990; C. Zeng, unpubl.). As we show here for the -5.6 to -4.5 minimal element, the function of many or perhaps all of these modules may be dependent on clusters of Dfd protein-binding sites. More detailed studies on the $D f d$ autoregulatory enhancer will be necessary to compare its overall structure and function to better characterized viral and mammalian enhancers, which are known to be organized from combinations of functional modules (for review, see Serfling et al. 1985; Dynan 1989).

As measured by immunoprecipitation assays, the binding specificity of the Dfd protein produced in E. coli appears to be similar to that of the Dfd protein present in the nuclear fraction of Drosophila embryo extracts. This indicates that other components of the nuclear extract do not appreciably change the selectivity of DNA binding by Dfd protein, at least on the $25 \mathrm{~kb}$ of DNA tested. However, because the 2.3-kb HindIII fragment had apparent higher affinity for the embryonic Dfd protein than for $E$. coli-produced Dfd protein, the absolute affinity for specific fragments may be altered by other embryonic factors or embryo-specific modifications of Dfd protein. Experiments on the DNA-binding properties of another homeotic selector protein, the Ubx protein, have shown that its ability to protect sequences from DNase digestion is indistinguishable whether the protein is produced in E. coli or in insect cells in tissue culture (Beachy et al. 1988). 
The two binding sites in the 900-bp fragment with the highest in vitro affinity for Dfd protein share a 7-base consensus: ATCATTA. This sequence is related to, but different from, consensus sequences defined for other homeo domain proteins (Fig. 5B). It appears to share the ATTA core that is part of many homeo domain-binding sites. However, the first 3 bases at the $5^{\prime}$ end of this sequence are unique to the Dfd consensus-binding site. It is possible that these few bases adjacent to the ATTA core make a large contribution to the ability of Dfd protein to selectively bind the $D f d$ autoregulatory element. These putative discriminator bases may also provide a structure that allows closely related homeo domain proteins to distinguish their preferred sites.

\section{Materials and methods}

Dfd protein from E. coli and embryos

Construction of the pAR3040Dfd expression plasmid has been described (Jack et al. 1988). Induction of Dfd protein expression in E. coli was carried out as described in Studier and Moffatt (1986). Induced cells were washed with $60 \mathrm{ml}$ of $20 \mathrm{~mm}$ HEPES (pH 7.6) and $200 \mathrm{mM} \mathrm{NaCl}$ at $4^{\circ} \mathrm{C}$ and resuspended in $6 \mathrm{ml}$ of lysis buffer at $4^{\circ} \mathrm{C}: 20 \mathrm{~mm}$ HEPES $(\mathrm{pH} 7.6), 200 \mathrm{~mm} \mathrm{NaCl}, 50 \mathrm{~mm}$ $\beta$-mercaptoethanol, $5 \mu \mathrm{g} / \mathrm{ml}$ of leupeptin, $5 \mu \mathrm{g} / \mathrm{ml}$ of pepstatin A, $2 \mu \mathrm{g} / \mathrm{ml}$ of aprotinin, $1 \mathrm{~mm}$ phenylmethylsulfonyl fluoride, 1 $\mathrm{mm}$ sodium metabisulfite, $2 \mathrm{~mm}$ benzamidine, $10 \%(\mathrm{wt} / \mathrm{vol})$ glycerol, $0.1 \mathrm{~mm}$ EDTA, and $0.5 \mathrm{mg} / \mathrm{ml}$ lysozyme. Cells were sonicated in $1.5-\mathrm{ml}$ aliquots three times for $5 \mathrm{sec}$ each with a microtip cell disruptor at the highest setting at $4^{\circ} \mathrm{C}$ (Branson Sonic Power Co. no. 350). Lysates were spun in a microcentrifuge for $30 \mathrm{~min}$ at $4^{\circ} \mathrm{C}$, and the soluble fractions were frozen at $-80^{\circ} \mathrm{C}$. The total protein concentration in the soluble extracts was $20-25 \mathrm{mg} / \mathrm{ml}$ as measured by the method of Bradford (1976). Aliquots were run on SDS-polyacrylamide gels (Laemmli 1970) and either stained with CBB G-250 or transferred to nitrocellulose for immunological detection of Dfd protein (Jack et al. 1988). The concentration of Dfd protein in the soluble extract as estimated from stained gels was $0.2-1.0 \mathrm{mg} / \mathrm{ml}$. Aliquots were kept at $-80^{\circ} \mathrm{C}$, thawed once, and used in the amounts described.

Nuclear extract from Drosophila hsp70-Dfd embryos was prepared as described by Biggin and Tiian (1988), as modified by Soeller et al. (1988). Embryos from a 6-hr collection were heatshocked at $37^{\circ} \mathrm{C}$ for $1 \mathrm{hr}$ and then processed. Aliquots of nuclear protein extract were kept at $-80^{\circ} \mathrm{C}$, thawed once, and used in the amounts described.

\section{Immunoprecipitations of DNA-protein complexes}

These experiments were done with slight modifications of the protocol of McKay (1981). DNA was digested with appropriate restriction enzymes, filled in with ${ }^{32} \mathrm{P}$-labeled nucleotides using Sequenase (U.S. Biochemicals; Sambrook et al. 1989), and DNA concentration was estimated by fluorometry in a Hoefer TKO 100 fluorometer. Fifty-microliter binding reactions contained 1 fmole of labeled DNA in the binding buffer $(210 \mathrm{mM} \mathrm{NaCl}, 20$ $\mathrm{mm}$ Tris at $\mathrm{pH} 7.5,0.25 \mathrm{~mm}$ EDTA, $10 \%$ glycerol, $1 \mathrm{~mm}$ DTT, $6.25 \mathrm{mM} \mathrm{MgCl}{ }_{2}, 0.05 \% \mathrm{NP}-40,100 \mu \mathrm{g} / \mathrm{ml}$ of sheared herring sperm DNA), and Dfd protein-containing extract (or purified Dfd protein) in the amounts described. After a 30-min incubation on ice, $15 \mu \mathrm{l}$ of Staphylococcus aureus cells (Calbiochem) preincubated with anti-Dfd antiserum was added, followed by another 30-min incubation on ice. The precipitated complexes were washed twice with binding buffer containing $10 \mu \mathrm{g} / \mathrm{ml}$ of sheared herring sperm DNA and extracted with a $1: 1$ volume of phenol/chloroform and ethanol-precipitated in the presence of $20 \mu \mathrm{g}$ of tRNA. Precipitated DNA was analyzed on either agarose or $5 \%$ denaturing polyacrylamide gels (Maniatis et al. 1989).

The $S$. aureus cell/anti-Dfd antibody complex was prepared as follows: $S$. aureus cells $(100 \mu \mathrm{l}$; formalin fixed, $10 \%$ solution; Calbiochem) were spun down, washed twice with binding buffer without competitor DNA, and resuspended in $500 \mu \mathrm{l}$ of anti-Dfd antiserum (Jack et al. 1988). Five hundred microliters of $100 \%$ glycerol was added to the mix and rotated on a Nutator (Clay Adams) at $4^{\circ} \mathrm{C}$ for at least $1 \mathrm{hr}$. The suspension was washed twice in the binding buffer containing $1 \mu \mathrm{g} / \mathrm{ml}$ of herring sperm competitor DNA and resuspended in 200-250 $\mu \mathrm{l}$ of binding buffer.

\section{DNase I protection}

DNase I protection experiments were done according to Heberlein et al. (1985), with some modifications. Each 50- $\mu$ l binding reaction contained 1 fmole of labeled DNA fragment, $25 \mu \mathrm{l}$ of $2 \times$ binding buffer (Heberlein et al. 1985), $2.5 \mu \mathrm{g}$ of poly[d(I-C)], and amounts of protein as indicated in the figure legends. After incubation for $30 \mathrm{~min}$ on ice, the binding reactions were treated with $20 \mathrm{ng}$ of DNase I in $10 \mu \mathrm{l}$ of $6 \times$ dilution buffer [ $10 \mathrm{~mm}$ Tris |pH 8.0| $1 \mathrm{~mm}$ EDTA, $15 \mathrm{mM} \mathrm{CaCl}_{2}, 30 \mathrm{mM} \mathrm{MgCl}_{2}$ ] on ice for 8 $\mathrm{min}$, and the reaction was stopped with $200 \mu \mathrm{l}$ of $10 \mathrm{~mm}$ EDTA containing $20 \mu \mathrm{g}$ of tRNA. DNA was then extracted with phenol/chloroform, and precipitated with ethanol. Samples were separated on $8 \%$ denaturing polyacrylamide gels and autoradiographed using Kodak AR film. The chemical sequencing protocol of Maxam and Gilbert (1977) was used to produce sequencing ladders of the same fragments used for footprinting.

\section{Construction and transformation of mutant autoregulatory elements}

A 920-bp HindIII-AlfII fragment containing the wild-type A-, B-, C-, and D-binding sites was subcloned into HZ50 la P-element transformation vector containing $h s p 70$ basal promoterlacZ reporter gene; Hiromi and Gehring 1987). This control construct, p920-HZ, was coinjected with p $\pi \Delta 2-3$ into $c n ; r y^{506}$ embryos as described previously (Rubin and Spradling 1982). Embryos $(350)$ were injected, and three separate transformed lines (920-HZ lines) were obtained. One line was homozygous lethal on the second chromosome. The other lines were both homozygous viable, with one on the second chromosome and the other on the third chromosome.

The pQ920-HZ construct was made exactly as described above except that the A-, B-, C-, and D-binding sites were mutated using 30-mer oligonucleotides according to the protocol of Kunkel et al. (1987). The CCCCC sequence in the middle of each oligonucleotide allowed a specific change at each binding site as shown in Figure 5 and was flanked by 12- and 13-bp "clamps" matching sequences around the binding sites. The mutated construct was coinjected with p $\Delta \Delta 2-3$ into $c n ; r y^{506}$ embryos. Embryos (497) were injected, yielding three separate Q920-HZ lines. All lines were homozygous viable, with one on the second, one on the third, and one on the fourth chromosome. To detect expression from the $920-\mathrm{HZ}$ and Q920-HZ constructs, embryos were collected over $6 \mathrm{hr}$ and aged for $12 \mathrm{hr}$ at $25^{\circ} \mathrm{C}$. They were then harvested, dechorionated, fixed in paraformaldehyde, and stained with mouse anti- $\beta$-galactosidase antibodies as described previously (Bergson and McGinnis 
1990). Three mutant and two wild-type strains were stained to eliminate the possibility that expression differences were due to insertion sites differences.

The quadruply mutated 900 -bp HindIII fragment was also used to replace the wild-type HindIII fragment in an $h s p 70$ basal promoter-lacZ vector that contained the $2.7-\mathrm{kb} \mathrm{XbaI}$ fragment $(-3.9$ to -6.6 ; Fig. 3). The pQ2.7-HZ construct that resulted is identical to $\mathrm{p} 2.7-\mathrm{HZ}$ (Bergson and McGinnis 1990) except for the mutations in sites A-D. Embryos from five independent transformed lines carrying the Q2.7-HZ fusion gene were tested for their pattern of expression of $\beta$-galactosidase.

\section{Acknowledgments}

We thank Mike Kuziora for reading and criticizing the manuscript, Tim Hoey for help in initiating the binding assays, and Clare Bergson for injecting Q2.7-HZ. We are also grateful to the National Institutes of Health (via PO1-GM39813) and the National Science Foundation Presidential Young Investigator program for research support.

The publication costs of this article were defrayed in part by payment of page charges. This article must therefore be hereby marked "advertisement" in accordance with 18 USC section 1734 solely to indicate this fact.

\section{References}

Akam, M.E. 1987. The molecular basis for metameric pattern in the Drosophila embryo. Development 101: 1-22.

Beachy, P.A., M.A. Krasnow, E.R. Gavis, and D.S. Hogness. 1988. An Ultrabithorax protein binds sequences near its own and the Antennapedia P1 promoters. Cell 55: 1069-1081.

Bergson, C. and W. McGinnis. 1990. An autoregulatory enhancer element of the Drosophila homeotic gene Deformed. $E M B O J$. (in press).

Bienz, M. and G. Tremml. 1988. Domain of Ultrabithorax expression in Drosophila visceral mesoderm from autoregulation and exclusion. Nature 333: 576-578.

Biggin, M.D. and R. Tjian. 1988. Transcription factors that activate the Ultrabithorax promoter in developmentally staged extracts. Cell 53: 699-711.

- 1989. A purified Drosophila homeodomain protein represses transcription in vitro. Cell 58: $433-440$.

Bradford, M. 1976. A rapid and sensitive method for the quantitation of microgram quantities of protein utilizing the principle of protein-dye binding. Anal. Biochem. 72: 248253.

Carrasco, A.E., W. McGinnis, W.J. Gehring, and E.M. DeRobertis. 1984. Cloning of a Xenopus laevis gene expressed during early embryogenesis coding for a peptide region homologous to Drosophila homeotic genes. Cell 37: 409-414.

Carroll, S.B., R.A. Layman, M.A. McCutcheon, P.D. Riley, and M.P. Scott. 1986. The localization and regulation of Antennapedia protein expression in Drosophila embryos. Cell 47: 113-122.

Chadwick, R. and W. McGinnis. 1987. Temporal and spatial distribution of transcripts from the Deformed gene of Drosophila. EMBO I. 6: 779-789.

Chadwick, R., B. Jones, T. Jack, and W. McGinnis. 1990. Ectopic expression from the Deformed gene triggers a dominant defect in Drosophila adult head development. Dev. Biol. 141: 130-140.

Dearolf, C.R., J. Topol, and C.S. Parker. 1989. The caudal+ gene product is a direct activator of fushi tarazu transcrip- tion during Drosophila embryogenesis. Nature 341: 340343.

Desplan, C., J. Theis, and P.H. O'Farrell. 1985. The Drosophila developmental gene, engrailed, encodes a sequence-specific DNA binding activity. Nature 318: 630-635.

- 1988. The sequence specificity of homeodomain-DNA interaction. Cell 54: 1081-1090.

Driever, W., G. Thoma, and C. Nüsslein-Volhard. 1989. Determination of spatial domains of zygotic gene expression in the Drosophila embryo by the affinity of binding sites for the bicoid morphogen. Nature 340: 363-367.

Driever, W. and C. Nüsslein-Volhard. 1989. The bicoid protein is a positive regulator of hunchback transcription in the early Drosophila embryo. Nature 337: 138-143.

Dynan, W.S. 1989. Modularity in promoters and enhancers. Cell 58: $1-4$

Fainsod, A., L.D. Bogarad, T. Ruusala, M. Lubin, D.M. Crothers, and F.H. Ruddle. 1987. The homeo domain of a murine protein binds 5 ' to its own homeo box. Proc. Natl. Acad. Sci. 83: 9532-9536.

Frigerio, G., M. Burri, D. Bopp, S. Baumgartner, and M. Noll. 1986. Structure of the segmentation gene paired and the Drosophila PRD gene set as part of a gene network. Cell 47: 735-746.

Galas, D. and A. Schmitz. 1978. DNase footprinting: A simple method for the detection of protein-DNA binding specificity. Nucleic Acids Res. 5: 3157-3170.

Garcia-Bellido, A. 1977. Homeotic and atavic mutations in insects. Am. Zool. 17: 613-629.

González-Reyes, A. and G. Morata. 1990. The developmental effect of overexpressing a Ubx product in Drosophila embryos is dependent on its interactions with other homeotic products. Cell 61: 515-522.

Hafen, E., M. Levine, and W.J. Gehring. 1984. Regulation of Antennapedia transcript distribution by the bithorax complex in Drosophila. Nature 307: 287-289.

Hall, M.N. and A.D. Johnson. 1987. Homeo domain of the yeast repressor alpha-2 is a sequence specific DNA-binding domain but is not sufficient for repression. Science 237: 10071012.

Han, K., M.S. Levine, and J.L. Manley. 1989. Synergistic activation and repression of transcription by Drosophila homeobox proteins. Cell 56: 573-583.

Heberlein, U., B. England, and R. Tjian. 1985. Characterization of Drosophila transcription factors that activate the tandem promoters of the alcohol dehydrogenase gene. Cell 41: 965977.

Hiromi, Y. and W.J. Gehring. 1987. Regulation and function of the Drosophila segmentation gene fushi tarazu. Cell 50: $963-974$.

Hoey, T. and M. Levine. 1988. Divergent homeo box proteins recognize similar DNA sequences in Drosophila. Nature 332: $858-861$.

Immerglück, K., P.A. Lawrence, and M. Bienz. 1990. Induction across germ layers in Drosophila mediated by a genetic cascade. Cell 62: 261-268.

Ingham, P.W. 1988. The molecular genetics of pattern formation in Drosophila. Nature 335: 25-34.

Jack, T., M. Regulski, and W. McGinnis. 1988. Pair-rule segmentation genes regulate the expression of the homeotic selector gene, Deformed. Genes \& Dev. 2: 635-651.

Jaynes, J.B. and P.H. O'Farrell. 1988. Activation and repression of transcription by homoeodomain-containing proteins that bind a common site. Nature 336: 744-749.

Krasnow, M.A., E.E. Saffman, K. Kornfeld, and D.S. Hogness. 1989. Transcriptional activation and repression by Ultra- 
bithorax proteins in cultured Drosophila cells. Cell 57: 1031-1043.

Kunkel, T.A., J.D. Roberts, and R.A. Zakour. 1987. Rapid and effective site-specific mutagenesis without phenotypic selection. Methods Enzymol. 154: 367-382.

Kuziora, M.A. and W. McGinnis. 1988. Autoregulation of a Drosophila homeotic selector gene. Cell 55: 477-485.

Laemmli, U.K. 1970. Cleavage of structural proteins during the assembly of the head of bacteriophage T4. Nature 227: 680682.

Lewis, E.B. 1978. A gene complex controlling segmentation in Drosophila. Nature 276: 565-570.

Maxam, A.M. and W. Gilbert. 1977. A new method for sequencing DNA. Proc. Natl. Acad. Sci. 74: 560-564.

McGinnis, W., M. Levine, E. Hafen, A. Kuroiwa, and W.J. Gehring. 1984a. A conserved DNA sequence found in homeotic genes of the Drosophila Antennapedia and Bithorax complexes. Nature 308: 428-433.

McGinnis, W., R.L. Garber, J. Wirz, A. Kuroiwa, and W.J. Gehring. 1984b. A homologous protein-coding sequence in Drosophila homeotic genes and its conservation in other metazoans. Cell 37: 403-408

McGinnis, W. 1985. Homeo box sequences of the Antennapedia class are conserved only in higher animal genomes. Cold Spring Harbor Symp. Quant. Biol. 50: 263-270.

McKay, R.D.G. 1981. Binding of a simian virus $40 \mathrm{~T}$ antigenrelated protein to DNA. I. Mol. Biol. 145: 471-488.

Merrill, V.K.L., F.R. Turner, and T.C. Kaufman. 1987. A genetic and developmental analysis of mutations in the Deformed locus in Drosophila melanogaster. Dev. Biol. 122: 379-395.

Muller, M., M. Affolter, W. Leupin, G. Otting, K. Wuthrich, and W.J. Gehring. 1988. Isolation and sequence-specific DNA binding of the Antennapedia homeodomain. EMBO $I$. 7: 4299-4304.

Muller, J., F. Thuringer, M. Biggin, B. Zust, and M. Bienz. 1989. Coordinate action of a proximal homeoprotein binding site and a distal sequence confers the Ultrabithorax expression pattern in the visceral mesoderm. EMBO /. 8: 4143-4151.

Pick, L., A. Schier, M. Affolter, T. Schmidt-Glenewinkel, and W. Gehring. 1990. Analysis of the $f t z$ upstream element: Germ layer-specific enhancers are independently autoregulated. Genes $\Leftrightarrow$ Dev. 4: 1224-1239.

Poole, S.J., L.M. Kauvar, B. Drees, and T. Kornberg. 1985. The engrailed locus of Drosophila: Structural analysis of an embryonic transcript. Cell 40: $37-43$.

Regulski, M., K. Harding, R. Kostriken, F. Karch, M. Levine and W. McGinnis. 1985. Homeo box genes of the Antennapedia and Bithorax complexes of Drosophila. Cell 43: 71-80.

Regulski, M., N. McGinnis, R. Chadwick, and W. McGinnis. 1987. Developmental and molecular analysis of Deformed: A homeotic gene controlling Drosophila head development. $E M B O$ I. 6: 767-777.

Rubin, G.M. and A.C. Spradling. 1982. Genetic transformation of Drosophila with transposable element vectors. Science 218: 348-353.

Sambrook, J., E.F. Fritsch, and T. Maniatis. 1989. Molecular cloning: A laboratory manual, 2nd. ed. Cold Spring Harbor Laboratory Press, Cold Spring Harbor, New York.

Scott, M.P. and A. Weiner. 1984. Structural relationships among genes that control development: Sequence homology between the Antennapedia, Ultrabithorax, and fushi tarazu loci of Drosophila. Proc. Natl. Acad. Sci. 81: 4115-4119.

Scott, M.P., J.W. Tamkun, and G.W. Hartzell III. 1989. The structure and function of the homeodomain. Biochim. Biophys. Acta 989: 25-48.

Serfling, E., M. Jasin, and W. Schaffner. 1985. Enhancers and eukayotic gene transcription. Trends Genet. 1: 224-230.

Soeller, W.C., S.J. Poole, and T. Kornberg. 1988. In vitro transcription of the Drosophila engrailed gene. Genes \& Dev. 2: 68-81.

Struhl, G. 1982. Genes controlling segmental specification in the Drosophila thorax. Proc. Natl. Acad. Sci. 79: 7380-7384.

Struhl, G., K. Struhl, and P.M. Macdonald. 1989. The gradient morphogen bicoid is a concentration-dependent transcriptional activator. Cell 57: 1259-1273.

Studier, F.W. and B.A. Moffatt. 1986. Use of bacteriophage T7 RNA polymerase to direct selective high-level expression of cloned genes. I. Mol. Biol. 189: 113-130.

Tautz, D. 1988. Regulation of the Drosophila segmentation gene hunchback by two maternal morphogenetic centers. Nature 332: 281-284.

Thali, M., M.M. Muller, M. DeLorenzi, P. Matthias, and M. Bienz. 1988. Drosophila homoeotic genes encode transcriptional activators similar to mammalian OTF-2. Nature 336: 598-600.

Wakimoto, B.T. and T.C. Kaufman. 1981. Analysis of larval segmentation in lethal genotypes associated with the Antennapedia gene complex in Drosophila melanogaster. Dev. Biol. 81: 51-64.

Way, J.C. and M. Chalfie. 1988. mec-3, a homeobox-containing gene that specifies differentiation of the touch receptor neurons in C. elegans. Cell 54: 5-16.

Winslow, G.M., S. Hayashi, M. Krasnow, D.S. Hogness, and M.P. Scott. 1989. Transcriptional activation by the Antennapedia and fushi tarazu proteins in cultured Drosophila cells. Cell 57: 1017-1030. 


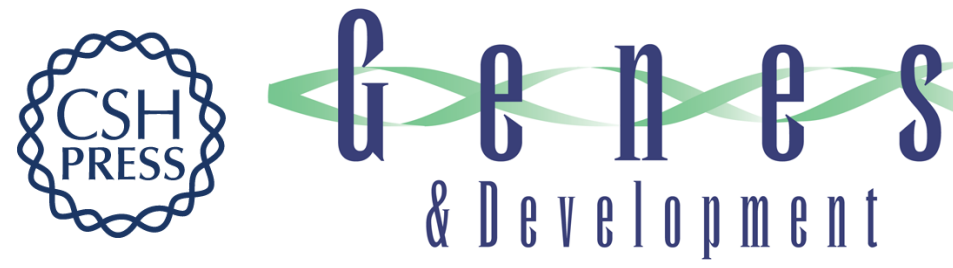

\section{High-affinity binding sites for the Deformed protein are required for the function of an autoregulatory enhancer of the Deformed gene.}

M Regulski, S Dessain, N McGinnis, et al.

Genes Dev. 1991, 5:

Access the most recent version at doi:10.1101/gad.5.2.278

References This article cites 61 articles, 10 of which can be accessed free at:

http://genesdev.cshlp.org/content/5/2/278.full.html\#ref-list-1

License

Email Alerting

Service

Receive free email alerts when new articles cite this article - sign up in the box at the top right corner of the article or click here.

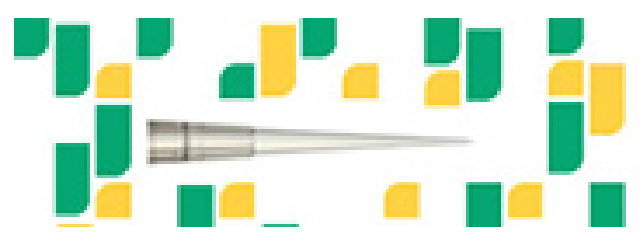

Focused on your science. 